Brit. Heart F., 1967, 29, 257.

\title{
Effect of Propranolol on Left Atrial Systole in Ischæmic and Hypertensive Heart Disease
}

\author{
JAMES FLEMING AND JOHN HAMER
}

From the Cardiac Department, St. Bartholomew's Hospital, London E.C.1

The sympathetic nervous system has an important effect on the strength of myocardial contraction which is mediated through beta-adrenergic receptors (Ahlquist, 1948), and the administration of a selective beta-adrenergic blocking agent such as propranolol might be expected to reduce myocardial contractility in patients who have a high sympathetic tone. There is evidence that patients in heart failure have increased activity of the sympathetic nervous system (Braunwald and Chidsey, 1965), which may act as a compensatory mechanism, increasing the strength of myocardial contraction and allowing the stroke output to be maintained at a lower diastolic pressure than would otherwise be possible. Under these circumstances beta-adrenergic blockade might be expected to have a deleterious effect on myocardial performance. In fact the development of cardiac failure is a recognized hazard of treatment with beta-adrenergic blocking drugs (Braunwald and Chidsey, 1965). These agents are now being used extensively in ischæmic and hypertensive heart disease, and reports have appeared of their value in reducing the severity of angina pectoris (Apthorp, Chamberlain, and Hayward, 1964), of their use in myocardial infarction (Snow, 1965), and of their hypotensive effect in systemic hypertension (Prichard and Gillam, 1964). The possibility that cardiac failure might be produced in patients with serious heart disease has necessarily restricted the use of beta-adrenergic blocking drugs in these conditions.

In this study an attempt has been made to assess the changes in diastolic tone of the left ventricle produced by beta-adrenergic blockade, so that patients likely to suffer from left ventricular failure after propranolol can be distinguished from those who will tolerate this treatment without difficulty. The diastolic properties of the left ventricle have

Received June 22, 1966. been studied by means of the apex cardiogram in patients suffering from ischæmic and hypertensive heart disease, before and after an intravenous injection of propranolol. Emphasis is placed on the changes produced by the drug during atrial systole, on the hypothesis that a tendency to aggravate left ventricular failure might be evident as an increase in the force of left atrial contraction, producing a larger presystolic increase in left ventricular volume. Particular attention has been given to the effects in patients with evidence of poor myocardial function.

\section{SUBJECTS AND METHODS}

Simultaneous apex cardiogram, phonocardiogram, and electrocardiogram were recorded with respiration held in the mid position after the patients had been resting comfortably for 20 minutes on their left side. The measurements were repeated 20 minutes after the intravenous injection of $5 \mathrm{mg}$. propranolol. The apex cardiogram was obtained with a Philips inductive displacement transducer PR 9310 (Fig. 1) which linearly records displacement with a frequency response from 0 to 50 cycles per second. The perspex ring holding the transducer was pressed firmly against the rib cage with the movable probe of the instrument at the point of maximum apical movement, and the tracing was recorded photographically at a paper speed of $80 \mathrm{~mm}$./ sec. The height of the presystolic wave was measured from its onset to its peak and was expressed as a percentage of the total amplitude of the apex cardiogram deflection, to eliminate differences caused by variation in sensitivity of the recording from patient to patient. The study was confined to patients with evidence of impaired myocardial function, as shown by a presystolic wave 10 per cent or more of the total deflection in the initial apex cardiogram.

Sixteen patients were studied: 12 suffered from ischæmic heart disease and $\mathbf{4}$ had severe systemic hypertension. All the patients with ischæmic heart disease had abnormal electrocardiograms, either with ST seg257 


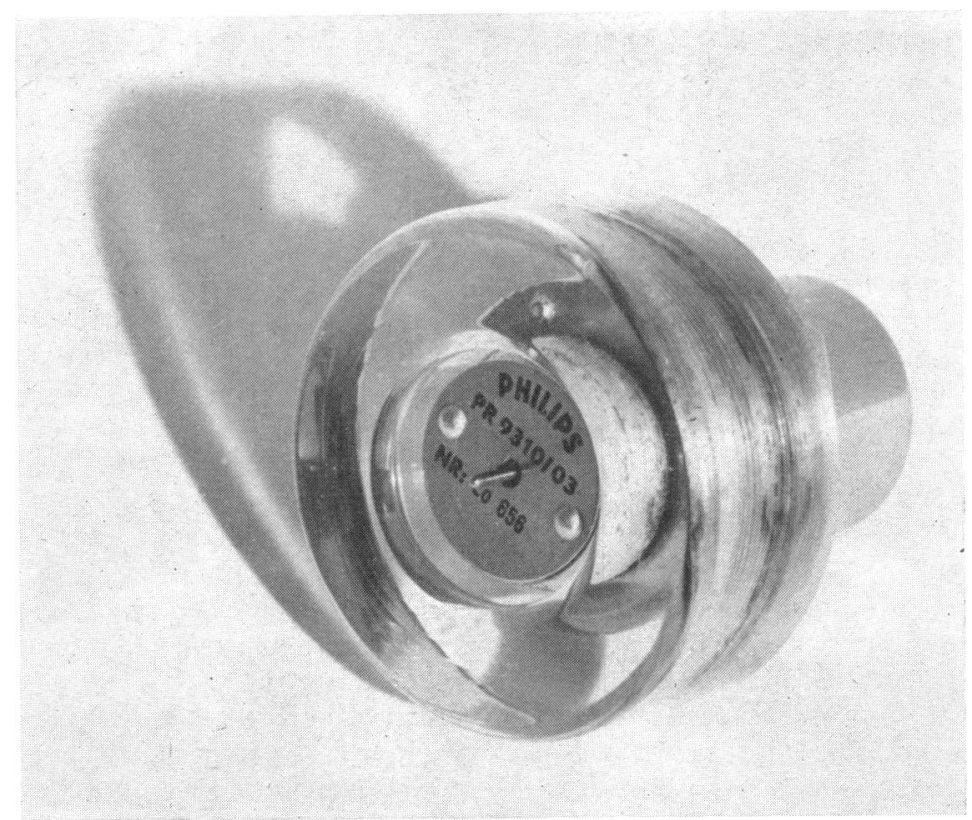

FIG. 1.-Philips inductive displacement transducer used to record the apex cardiograms in the present study.

or electrocardiographic evidence of myocardial infarction (Table I). The patients chosen were in sinus rhythm and none was studied less than three weeks after a clinical myocardial infarction. A cardiothoracic ratio greater than 50 per cent, evidence of pulmonary venous congestion on the chest radiograph (Fig. 2), or a recent history of paroxysmal dyspnœa were regarded as evidence of the presence of left ventricular failure. The six patients with clinical evidence of left ventricular failure were classed as group $B$, the remaining 10 patients forming group A (Table II).

\section{Results}

The results are presented in Table II. In all but one case slowing of the heart rate followed the intravenous administration of propranolol, pro-

TABLE I

CLINICAL FEATURES OF PATIENTS STUDIED

\begin{tabular}{|c|c|c|c|c|}
\hline \multirow[t]{2}{*}{ Diagnosis } & \multirow{2}{*}{$\begin{array}{c}\text { Attacks of } \\
\text { paroxysmal } \\
\text { dyspnca }\end{array}$} & \multirow[t]{2}{*}{ Electrocardiogram } & \multicolumn{2}{|c|}{ Chest radiograph } \\
\hline & & & $\begin{array}{c}\text { Enlarged } \\
\text { transverse } \\
\text { diameter } \\
\text { of heart }\end{array}$ & $\begin{array}{l}\text { Congested } \\
\text { lung } \\
\text { fields }\end{array}$ \\
\hline \multicolumn{5}{|l|}{ Group $A$ : No left ventricular failure } \\
\hline $\begin{array}{l}\text { Systemic hypertension } \\
\text { Ischæmic heart disease } \\
\text { Ischæmic heart disease } \\
\text { Ischæmic heart disease } \\
\text { Ischæmic heart disease } \\
\text { Ischæmic heart disease } \\
\text { Ischæmic heart disease } \\
\text { Systemic hypertension } \\
\text { Ischæmic heart disease } \\
\text { Ischæmic heart disease }\end{array}$ & $\begin{array}{l}0 \\
0 \\
0 \\
0 \\
0 \\
0 \\
0 \\
0 \\
0 \\
0\end{array}$ & $\begin{array}{l}\text { Severe LV hypertrophy } \\
\text { Old myocardial infarct } \\
\text { Old myocardial infarct } \\
\text { Extensive ischæmic changes } \\
\text { Ischæmic ST segment depression } \\
\text { Ischæmic ST segment depression } \\
\text { Old myocardial infarct } \\
\text { Severe LV hypertrophy } \\
\text { Recent myocardial infarct } \\
\text { Ischæmic ST segment depression }\end{array}$ & $\begin{array}{l} \pm \\
\pm \\
\pm \\
0 \\
0 \\
0 \\
\pm \\
0 \\
0 \\
0\end{array}$ & $\begin{array}{l}0 \\
0 \\
u \\
0 \\
0 \\
0 \\
0 \\
0 \\
0 \\
0\end{array}$ \\
\hline \multicolumn{5}{|l|}{ Group B: Left ventricular failure } \\
\hline $\begin{array}{l}\text { Malignant hypertension } \\
\text { Malignant hypertension } \\
\text { Ischæmic heart disease } \\
\text { Ischæmic and hypertensive heart disease } \\
\text { Ischæmic heart disease } \\
\text { Ischæmic heart disease }\end{array}$ & $\begin{array}{l}++ \\
++ \\
++ \\
+ \\
+ \\
+\end{array}$ & $\begin{array}{l}\text { Severe LV hyptertrophy } \\
\text { Severe LV hyptertrophy } \\
\text { LV aneurysm } \\
\text { LBBB } \\
\text { LV parietal block } \\
\text { Myocardial infarction }\end{array}$ & $\begin{array}{l}++ \\
++ \\
++ \\
+ \\
++\end{array}$ & $\begin{array}{l}+++ \\
++t \\
++t \\
++ \\
+\end{array}$ \\
\hline
\end{tabular}

LBBB = Left bundle-branch block. 

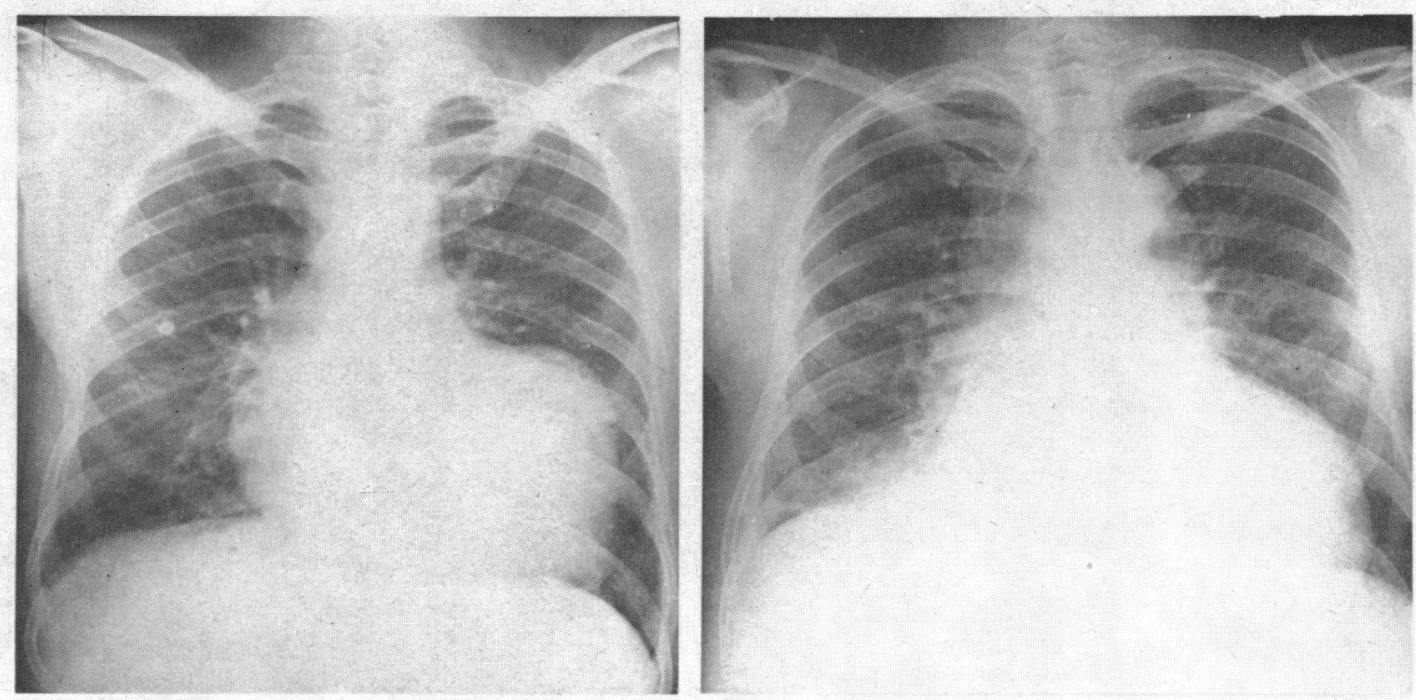

FIG. 2.-Chest radiographs in patients with clinical evidence of left ventricular failure (group B).

viding evidence that beta-sympathetic blockade had been produced. The effect of propranolol on the height of the presystolic wave in the left ventricle differed in Group A and Group B. In the absence of heart failure (Group A), there was a reduction in the size of the presystolic wave (Fig. 3) in every patient, with a mean fall of 28 per cent from the initial value, and this change is statistically significant (using the $t$ test, $p<0.01$ ). In Group $B$, the patients with left ventricular failure, the presystolic wave was increased in 4 (Fig. 4) and reduced in 2 subjects, but there was no significant trend (mean increase 10\%). The changes are shown diagrammatically in Fig. 5.

TABLE II

CHANGES IN PRESYSTOLIC WAVE OF APEX CARDIOGRAM AFTER PROPRANOLOL

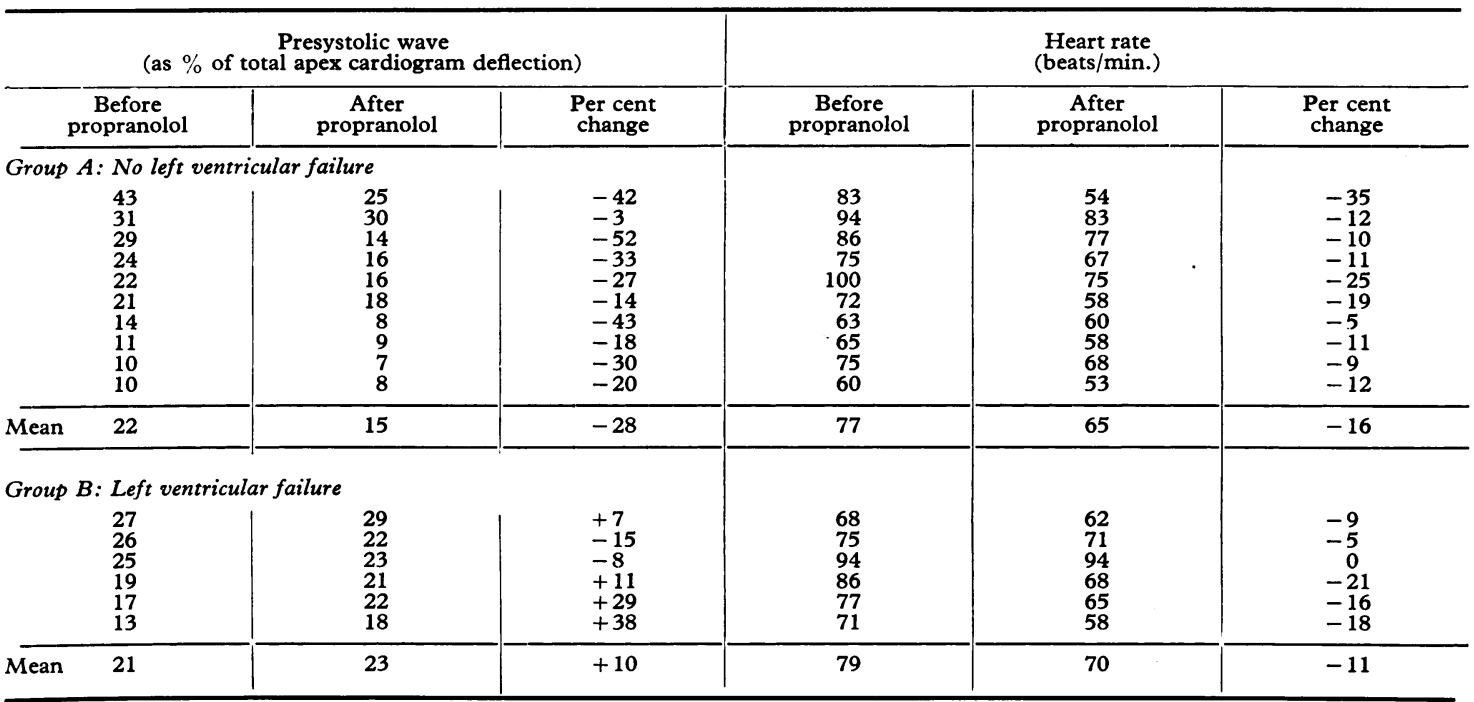




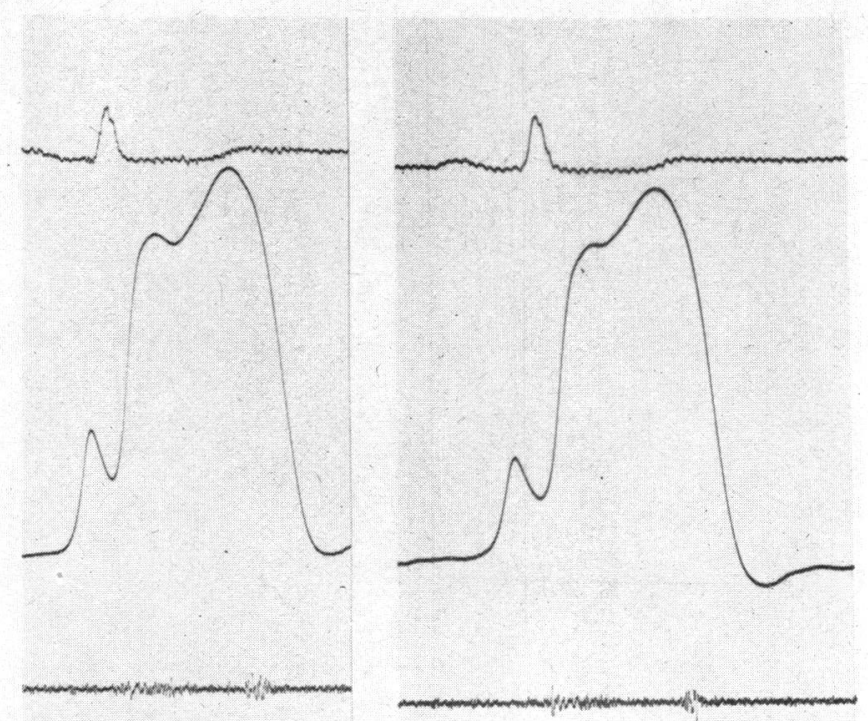

FIg. 3.-Apex cardiogram before and after propranolol in a patient with no evidence of left ventricular failure, showing a reduction in the presystolic thrust after propranolol.

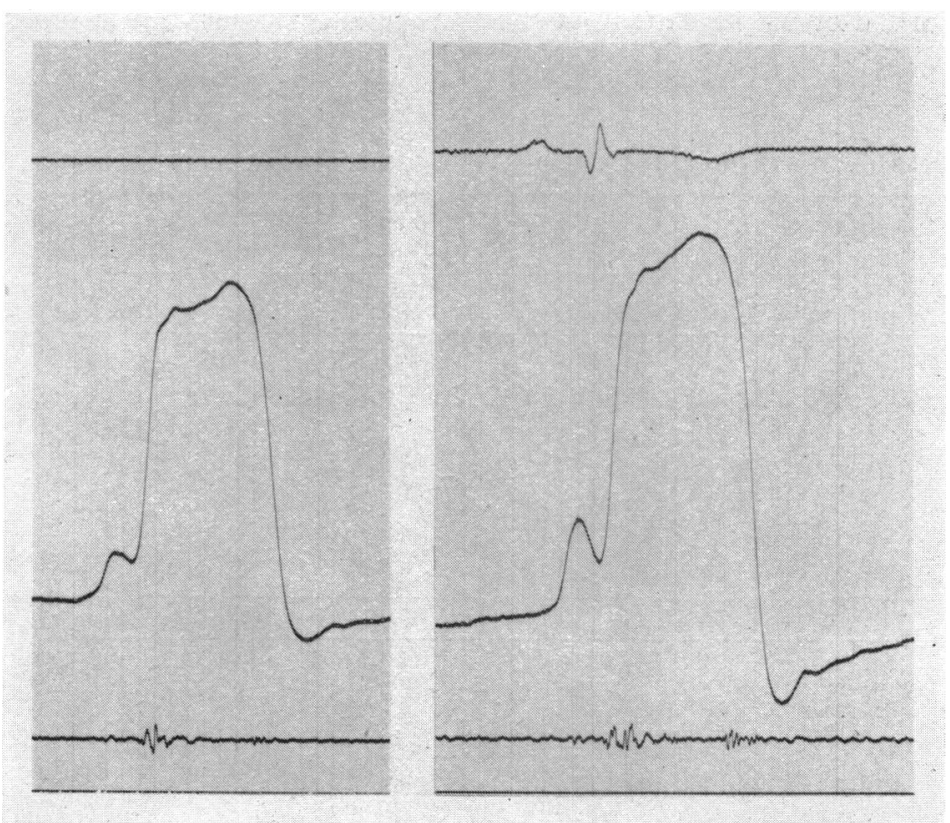

FIG. 4.-Apex cardiogram before and after propranolol in a patient with left ventricular failure, showing an increase in the presystolic thrust after propranolol. 
A

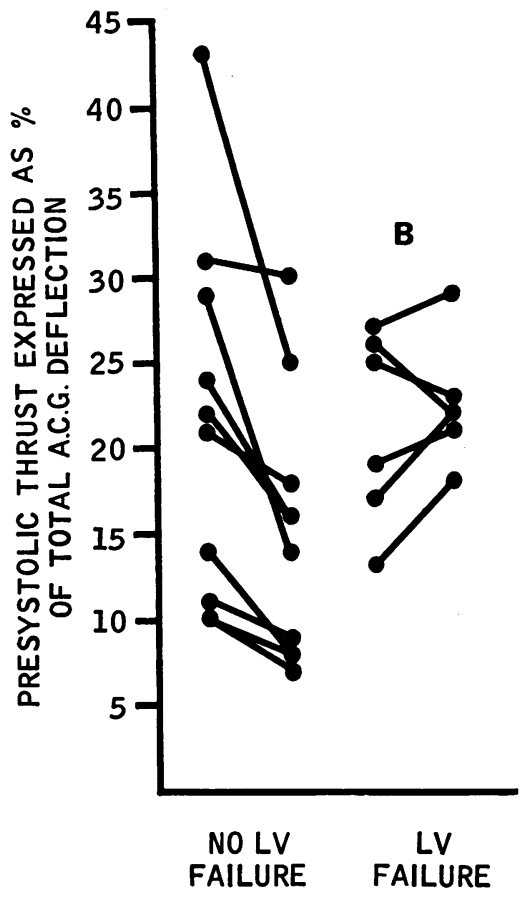

Fig. 5.-Changes in the presystolic thrust of the apex cardiogram produced by propranolol expressed as a percentage of the total deflection. Group A, with no left ventricular failure, show a consistent reduction in the presystolic thrust. Group B, with left ventricular failure, show an increase in the presystolic thrust in some patients.

\section{Discussion}

Intravenous propranolol in patients with impaired myocardial function but no overt failure (Group A) has been shown to reduce the size of the presystolic thrust in the apex cardiogram. The presystolic wave represents an increase in the volume of the left ventricle in response to left atrial contraction (Tavel et al., 1965; Tafur, Cohen, and Levine, 1964). It can, therefore, be inferred that the left atrial systolic contribution to left ventricular volume is less after intravenous propranolol in these patients. There are several ways in which this might be brought about.

Changes in Distensibility of Left Ventricle. Betaadrenergic blockade might decrease the distensibility of the left ventricular muscle. Left atrial contraction would then be expected to produce a smaller change in left ventricular volume, the pressure-volume relationship of the ventricle moving to a different curve (Fig. 6). However, this mechanism seems unlikely to be responsible for

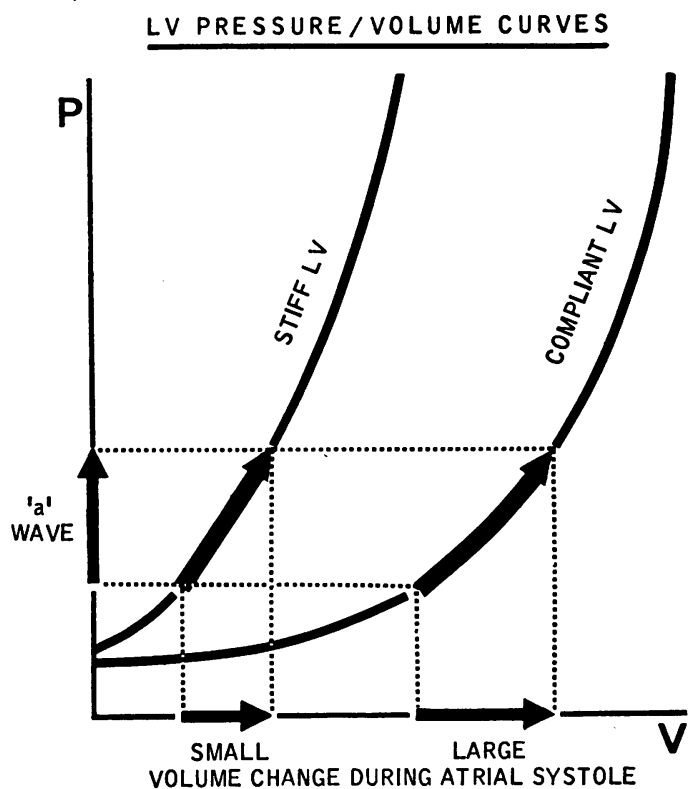

FIG. 6.-The effect of decreased distensibility of the left ventricle on the change in volume produced by left atrial systole. The difference in distensibility is expressed as two pressure-volume curves. Left atrial contraction produces a smaller volume change in a less distensible left ventricle.

the changes found in the present study, as Mitchell, Linden, and Sarnoff (1960) have demonstrated that cardiac sympathetic stimulation does not produce a change in myocardial distensibility except at very rapid heart rates. Benchimol and Dimond (1962) have shown that the height of the presystolic wave in the apex cardiogram correlates well with the size of the left atrial systolic pressure wave under a variety of circumstances. Also, hypertrophic obstructive cardiomypathy is usually associated with a very large presystolic wave (Fig. 7), though the distensibility of the ventricle is much reduced. We have therefore considered other possible mechanisms for the reduction in the presystolic thrust.

Increase in Diastolic Volume of Left Ventricle. If the volume of the left ventricle in diastole is increased, a normal increment in volume produced by left atrial systole will necessarily have a proportionately smaller effect. In addition, a given pressure change will produce a smaller change in volume as the pressure-volume curve is steeper in a distended ventricle (Fig. 8). Both these effects will tend to produce a small presystolic wave in the apex cardiogram at large left ventricular volumes.

Beta-adrenergic blockade slows the heart so that a 


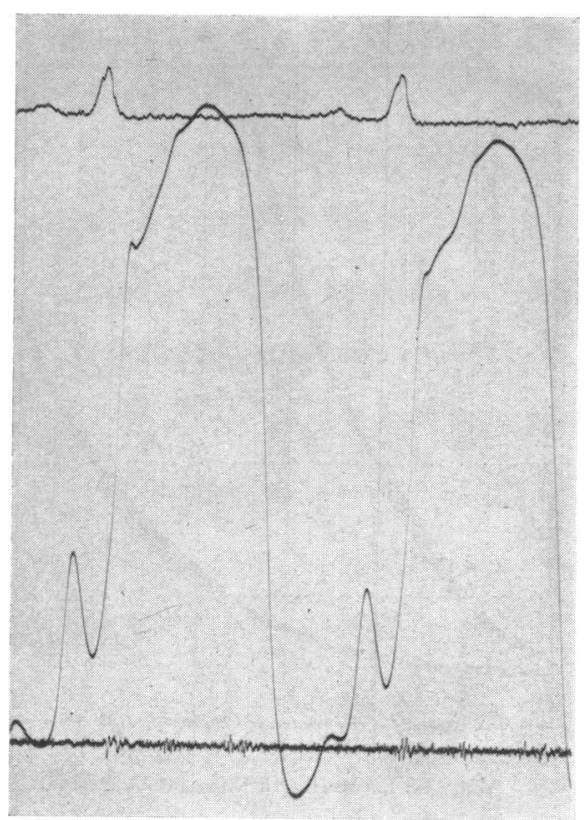

Frg. 7.-Apex cardiogram in a patient with hypertrophic obstructive cardiomyopathy showing a prominent presystolic thrust.

\section{PRESSURE/VOLUME CURVE}

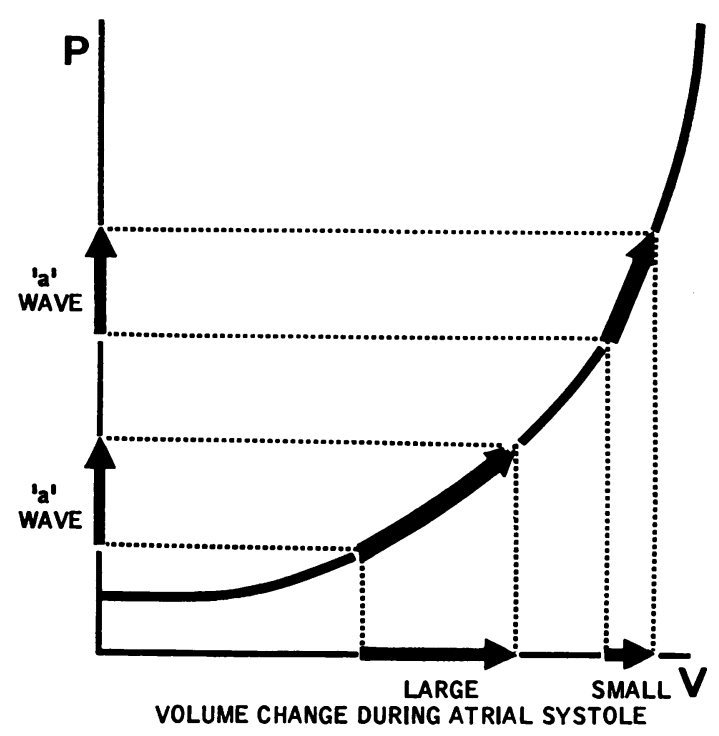

FIG. 8. - The effect of a greater left ventricular volume on the change in volume produced by left atrial systole. The increasing slope of the pressure-volume curve, indicating decreased distensibility at larger volumes, produces a smaller change in volume for a given change in pressure from left atrial systole. greater stroke volume is needed to maintain the cardiac output. There is evidence that the ratio between the stroke volume and the end-diastolic volume of the left ventricle remains constant under varying circumstances (Miller and Swan, 1964), and on these grounds it seems likely that the enddiastolic volume of the left ventricle might be increased after propranolol. Cine-radiological studies of the effects of beta-adrenergic stimulation (Harrison et al., 1964) or blockade (Chamberlain, 1966) in normal subjects support this suggestion. However, there is evidence that the cardiac output in patients with ischæmic heart disease falls after the administration of propranolol so that there is little change in stroke volume (Hamer and Sowton, 1965). The increase in left ventricular volume expected on the basis of a greater stroke volume seems too small to account for the striking reduction in the presystolic waves produced by propranolol in the patients studied here.

Decreased Force of Left Atrial Contraction. The reduction of myocardial contractility after sympathetic blockade will affect the atrial as well as the ventricular myocardium. A decrease in the force of left atrial contraction on this basis seems the most likely explanation for the observed diminution in height of the presystolic wave after intravenous propranolol in our patients with impaired myocardial function but no overt failure (Group A). A forceful left atrial contraction is an important contribution to left ventricular performance under stress, as it allows the ventricle to contract from a longer end-diastolic fibre length, and, therefore, more powerfully, with a minimal rise in mean left atrial pressure.

It is of interest that 4 of our 6 patients in left ventricular failure (Group B) did not have a reduction in the presystolic wave following intravenous propranolol. The usual response to betaadrenergic blockade might be attributed to a reduced natural cardiac sympathetic tone in these patients. Although there is evidence that cardiac sympathetic activity is increased in heart failure, assay of myocardial tissue from both atria and ventricles shows a reduction in catecholamine content, and the response to sympathetic stimulation is reduced (Braunwald and Chidsey, 1965). Patients with left ventricular failure studied here usually showed slowing of the heart rate after propranolol. It seems likely that the mechanism of the sympathetic chronotropic and inotropic effects is in fact identical at the cellular level (Vaughan Williams, 1966), so bradycardia may be regarded as evidence of a persistent action of propranolol on myocardial contraction in these patients. 
Starling Effect in Left Atrium. The increased ' $a$ ' wave in the apex cardiogram after propranolol in some patients with left ventricular failure may be secondary to a further increase in mean left atrial pressure. The impaired ventricular myocardial contractility produced by beta-adrenergic blockade might be expected to lead to a rise in the filling pressure of the left ventricle to restore myocardial performance by increasing the initial tension of the muscle fibres, as demonstrated by Starling (1918). The consequent increase in left atrial pressure will lead to greater distension of this chamber. As the Starling mechanism applies to atrial as well as to ventricular muscle, the increase in length of the atrial muscle fibres during atrial diastole will produce a more forceful left atrial contraction. It seems likely that when the mean left atrial pressure is high this indirect effect predominates over the reduction in left atrial contraction that follows withdrawal of atrial sympathetic tone.

From this analysis it seems likely that an increase in the presystolic wave in the apex cardiogram after propranolol is evidence of a serious effect on left ventricular function. The patients with an increase in the presystolic wave in the present study all had severe disease (Table I and Fig. 2), and in our view propranolol is contraindicated in this group. In other patients with left ventricular stress a reduction in the presystolic wave indicates less serious interference with left ventricular function, but must be regarded as evidence of some disturbance of the response of the heart to an increased load. Treatment with propranolol is clearly not free from risk, but on present evidence the danger of left ventricular failure seems less in these patients.

\section{SUMMARY}

The effect of sympathetic blockade on the abnormally large presystolic thrust in the apex cardiogram was studied in 16 patients with ischæmic and hypertensive heart disease. There was a marked reduction in the presystolic wave after intravenous propranolol in all 10 patients with no left ventricular failure. Four of the six patients with clinical evidence of left ventricular failure had larger presystolic waves after propranolol.

Possible mechanisms are considered. A change in left ventricular distensibility is thought unlikely, and the effect of an increase in ventricular volume related to the slowing of the heart is not sufficient to account for the changes. A reduction in left atrial contractility is probably responsible for the reduced presystolic thrust in patients with no left ventricular failure. The increased thrust noted in patients with left ventricular failure may be due to the Starling response to a rise of left atrial pressure.

The therapeutic implications of these findings are discussed.

We are grateful to Imperial Chemical Industries Limited, Pharmaceutical Division, for enabling us to purchase the apparatus for apex cardiography, and to Dr. Bernard Watson of the Department of Medical Electronics, St. Bartholomew's Hospital, for technical advice.

\section{REFERENCES}

Ahlquist, R. P. (1948). A study of the adrenotropic receptors. Amer. F. Physiol., 153, 586.

Apthorp, G. H., Chamberlain, D. A., and Hayward, G. W. (1964). The effects of sympathectomy on the electrocardiogram and effort tolerance in angina pectoris. Brit. Heart f., 26, 218.

Benchimol, A., and Dimond, E. G. (1962). The apex cardiogram in ischæmic heart disease. Brit. Heart $\mathcal{F}$., 24, 581.

Braunwald, E., and Chidsey, C. A. (1965). The adrenergic nervous system in the control of the normal and failing heart. Proc. roy. Soc. Med., 58, 1063.

Chamberlain, D. A. (1966). Presented at the symposium on Propranolol at Buxton 1965. Amer. F. Cardiol, 18, 321.

Hamer, J., and Sowton, E. (1965). Cardiac output after beta-adrenergic blockade in ischæmic heart disease. Brit. Heart f., 27, 892.

Harrison, D. C., Glick, G., Goldblatt, A., and Braunwald, E. (1964). Studies on cardiac dimensions in intact, unanesthetized man. Part IV. Effects of isoproperenol and methoxamine. Circulation, 29, 186.

Miller, G. A. H., and Swan, H. J. C. (1964). Effect of chronic pressure and volume overload on left heart volumes in subjects with congenital heart disease. Circulation, 30, 205.

Mitchell, J. H., Linden, R. J., and Sarnoff, S. J. (1960). Influence of cardiac sympathetic and vagal nerve stimulation on the relation between left ventricular diastolic pressure and myocardial segment length. Circulat. Res., 8, 1100.

Prichard, B. N. C., and Gillam, P. M. S. (1964). Use of propranolol (Inderal) in treatment of hypertension. Brit. med. F., 2, 725 .

Snow, P. J. D. (1965). Effect of propranolol in myocardial infarction. Lancet, 2, 551.

Starling, E. H. (1918). The Linacre Lecture on the Law of the Heart. Longmans, Green, London.

Tafur, E., Cohen, L. S., and Levine, H. D. (1964). The normal apex cardiogram. Circulation, 30, 381.

Tavel, M. E., Campbell, R. W., Feigenbaum, H., and Steinmetz, E. F. (1965). The apex cardiogram and its relationship to hæmodynamic events within the left heart. Brit. Heart f., 27, 829.

Vaughan Williams, E. M. (1966). Presented at the symposium on Propranolol at Buxton, 1965. Amer. F. Cardiol, 18, 399. 